\title{
Motivasi Belajar Siswa Dan Keterlibatan Siswa Dalam Pembelajaran Daring Pendidikan Jasmani
}

\author{
Tatang Suryadin ${ }^{1}$, Taufik Hidayat ${ }^{2}$ \\ ${ }^{12}$ Universitas Majalengka, Majalengka, Indonesia, 45418 \\ ttngsuryadin@unma.ac.id ${ }^{1}$, taufik2799@gmail.com²
}

\begin{abstract}
This research aims to find out students' learning motivation and student involvement in online learning of physical education to the Junior Highschool students at SMPN 1 Arjawinangun. This research is a survey study using a quantitative descriptive approach. The instruments in this study used quisioner, while the sampling technique was simple random sampling. With a sample number of 92 students. Analysis of the data used in this study is a quantitative descriptive analysis with percentages.

The results of this study show the motivation of learning students in online learning of physical education in SMPN 1 Arjawinangun. In detail it shows the motivation for learning students in the high category with an average of 92 respondents of 94.43 (78.70\%). Motivation to study students in online learning physical education which is very high thanks to 31 students (34\%), high in number 60 students (65\%), low in 1 student (1\%) and very low in number of 0 students (0\%). Whereas the results of research on student involvement in online learning of physical education in the high category, with an average of 92 respondents of 59.97 or (74.96\%). Student involvement in online learning physical education which is very highly categorized by 15 students (16\%), high in 75 students (82\%), low in 2 students (2\%) and very low in 0 students (0\%).
\end{abstract}

Keywords: students' learning motivation, student involvement, and online learning

ABSTRAK. Penelitian ini bertujuan untuk mengetahui motivasi belajar siswa dan keterlibatan siswa dalam pembelajaran daring pendidikan jasmani di SMPN 1 Arjawinangun. Penelitian ini merupakan penelitian survei dengan menggunakan pendekatan deskriptif kuantitatif. Instrumen dalam penelitian ini menggunakan angket, sedangkan teknik samplingnya adalah simple random sampling. Dengan jumlah sampel 92 siswa. Analisis data yang digunakan dalam penelitian ini adalah analisis deskriptif kuantitatif dengan persentase.

Hasil penelitian ini menunjukkan motivasi belajar siswa dalam pembelajaran daring pendidikan jasmani di SMP N 1 Arjawinangun. Secara terperinci menunjukkan motivasi belajar siswa pada kategori tinggi dengan rata-rata dari 92 responden sebesar $94,43(78,70 \%)$. Motivasi belajar siswa dalam pembelajaran daring pendidikan jasmani yang berkategori sangat tinggi berjumlah 31 siswa (34\%), tinggi berjumlah 60 siswa (65\%), rendah 1 siswa (1\%) dan sangat rendah berjumlah 0 siswa (0\%). Sedangkan hasil penelitian keterlibatan siswa dalam pembelajaran daring pendidikan jasmani pada kategori tinggi, dengan rata-rata dari 92 responden sebesar 59,97 atau (74,96\%). Keterlibatan siswa dalam pembelajaran daring pendidikan jasmani yang berkategori sangat tinggi berjumlah 15 siswa (16\%), tinggi berjumlah 75 siswa (82\%), rendah 2 siswa (2\%) dan sangat rendah berjumlah 0 siswa (0\%).

Kata Kunci : motivasi belajar siswa, keterlibatan siswa, pembelajaran daring

\section{PENDAHULUAN}

Pembelajaran merupakan proses interaksi peserta didik dengan pendidik dan sumber belajar pada suatu lingkungan belajar. Pada masa-masa normal pembelajaran ini berjalan secara langsung (tatap muka), akan tetapi dampak wabah virus covid-19 yang melanda Indonesia berimbas pada proses pembelajaran di sekolah. Kemendikbud 


\section{Journal Respecs}

mengeluarkan surat edaran tentang pembelajaran secara daring dan bekerja dari rumah dalam rangka pencegahan penyebaran virus covid-19.

Pembelajaran daring adalah pembelajaran yang dilakukan tanpa melakukan tatap muka, tetapi melalui platform digital yang telah tersedia. Pembelajaran elektronik (eLearning) merupakan pembelajaran yang memanfaatkan jaringan Internet sebagai metode penyampaian, Interaksi, dan fasilitasi serta didukung oleh berbagai bentuk layanan belajar lainnya (Nurdyansyah dan Fahyuni, 2017). Dalam pembelajaran daring ini Guru dan siswa melakukan kegiatan belajar mengajar menggunakan aplikasi seperti zoom, google classroom, whatsapp dsb.

Akan tetapi dalam pembelajaran pendidikan jasmani yang identik dengan aktivitas gerak, pembelajaran daring ini tentu akan mengalami berbagai kendala yang diantaranya, belum semua siswa memiliki smartphone, kouta internet yang terbatas, tidak semua guru mampu membuat media pembelajaran untuk menyampaikan materi pembelajaran melalui daring. Kesemua itu tentu akan berdampak pada motivasi belajar dan keterlibatan siswa dalam pembelajaran pendidikan jasmani secara daring. Ujung dari semua itu adalah keberhasilan dalam mencapai tujuan pembelajaran di sekolah.

Terlepas dari permasalahan-permasalahan yang dihadapi dalam pembelajaran daring, khususnya dalam pelajaran pendidikan jasmani. Pada tahun 2021 ini, kita memasuki tahun kedua menggunakan pembelajaran daring. Artinya berbagai adaptasi telah kita laksanakan dan rasakan selama tahun pertama penerapan pembelajaran daring. Berbagai perencanaan hingga evaluasi penerapan berbagai aplikasi, media dan metode pembelajaran telah kita tempuh pada tahun 2020. Untuk itu penulis merasa perlu melakukan penelitian bagaimana dampaknya pembelajaran daring yang telah kita terhadap motivasi belajar dan keterlibatan siswa dalam pembelajaran pendidikan jasmani secara daring pada tahun 2021.

Pencapaian tujuan pembelajaran sangat berkaitan dengan menumbuhkan motivasi siswa dalam belajar. Motivasi adalah suatu dorongan eksternal dan internal yang ada pada diri individu untuk mencapai sebuah tujuan. Motivasi belajar merupakan sesuatu keadaan yang terdapat pada diri seseorang individu dimana ada suatu dorongan untuk melakukan sesuatu guna mencapai tujuan. (Emda, 2017). Motivasi ini akan berpengaruh pada upayaupaya siswa dalam menguasai materi pelajaran. Dengan motivasi yang tinggi akan membuat siswa lebih intens dalam belajarnya. 


\section{Journal Respecs}

Motivasi juga berhubungan dengan keterlibatan siswa dalam proses belajarnya. Keterlibatan siswa adalah perwujudan dari motivasi yang dilihat melalui tindakan, kognitif, dan emosi yang ditampilkan oleh siswa, mengacu pada tindakan berenergi, terarah, dan tetap bertahan ketika mendapatkan kesulitan atau kualitas siswa dalam interaksinya dengan tugas akademik. (Ariani, 2019). Keterlibatan ini dapat diartikan bahwa sesuatu yang menunjukkan peran aktif dari seorang siswa dalam melakukan suatu aktivitas pembelajaran. Seperti : bertanya, mengajukan pendapat, mengerjakan dan bertanggung jawab pada tugas-tugas yang diberikan, dan bisa bekerjasama dengan siswa lain.

Motivasi belajar pada siswa yang mengikuti pembelajaran daring di tengah situasi pandemi virus covid-19 ini menurun. Faktor eksternal seperti kondisi lingkungan belajar memberikan pengaruh terhadap menurunnya motivasi belajar siswa (Cahyani dkk, 2020). Kondisi lingkungan belajar daring mengharuskan siswa untuk belajar di rumahnya masing-masing, guru tidak dapat mendampingi dan mendidik siswa secara langsung sehingga guru tidak dapat melalukan tindakan seperti memberi hadiah, memuji, menegur, menghukum, dan memberikan nasihat. Padahal tindakan-tindakan guru tersebut dapat menguatkan motivasi intrinsik siswa.

Tingkat partisipasi siswa dalam pembelajaran daring di masa pandemi Covid-19 di SMP N Kalijambe, menunjukkan tingkat partisipasi pembelajaran pada masa pandemi Covid-19 tergolong tinggi. Namun adanya beberapa hambatan dalam pelaksanaan aktivitas belajar daring yang diharapkan bisa menjadi evalusi kedepan (Purbawati Dkk, 2020). Hambatan tersebut terkait dengan pemanfaatan dan pemilihan media daring yang sekiranya mudah dijangkau oleh peserta didik, seperti aplikasi WhatsApp, Zoom, Google Meet, dan Schoology.

Penerapan pembelajaran daring dalam pelajaran pendidikan jasmani tentu lebih rumit dari pelajaran di kelas. Penelitian terkait penerapan pembelajaran daring pendidikan jasmani dari sudut pandang siswa mengungkapkan bahwa sebagian besar siswa menyatakan pembelajaran daring untuk pendidikan jasmani olahraga dan kesehatan sepenuhnya belum efektif dan belum baik. (Komarudin dan Prabowo, 2020). Lebih lanjut dari sudut pandang guru, Dalam proses pembelajaran daring, guru memiliki batas kemampuan untuk mengoperasikan berbagai aplikasi yang digunakan dalam menyampaikan materi pelajaran kepada siswa, keterbatasan tersebut berhubungan dengan 


\section{Journal Respecs}

sarana, peralatan dan penguasaan teknologi yang di miliki masing-masing sekolah, Guru, siswa serta letak geografis. (Hudah dkk, 2020). Dua penelitian tersebut menggambarkan bahwa baik siswa maupun guru masih banyak menemui berbagai hambatan dalam melaksanakan pembelajaran daring.

Namun jika merujuk pada teori kebutuhan (Need Teory) yang diungkapkan Abraham Maslow, kita bisa berasumsi bahwa pada dasarnya siswa maupun guru ingin bertahan (survive) dan memperoleh kebermaknaan dalam hidupnya. Pembelajaran daring yang dilaksanakan pada tahun 2020 dirasakan sebagai beban yang berat dengan berbagai kendala yang dihadapi. Pada tahun 2021 baik siswa maupun guru telah beradaptasi dengan segala tantangan itu.

\section{METODE PENELITIAN}

Penelitian ini menggunakan penelitian survei. Metode survei adalah metode penelitian yang menggunakan kuesioner sebagai instrumen utama untuk mengumpulkan data. (Siyoto dan Sodik, 2015). Dalam penelitian ini survei yang dilakukan dengan cara mengumpulkan informasi dari sejumlah siswa menggunakan kuesioner sebagai instrumennya.

Dalam penelitian ini yang menjadi populasi penelitian adalah seluruh siswa SMPN 1 Arjawinangun dengan jumlah 1041 siswa, terbagi menjadi kelas VII, kelas VIII dan Kelas IX.

Teknik pengambilan sampel pada penelitian ini menggunakan probability sampling dalam bentuk simple random sampling. Teknik pengambilan sampel dengan cara probabilitas selalu mengacu bahwa setiap subjek dalam populasi memiliki peluang yang besarnya sudah diketahui untuk terpilih menjadi sampel. (Badriah, 2012) Alasan menggunakan teknik simple random sampling adalah menerapkan asas tanpa pilih-pilih, sehingga setiap anggota populasi mempunyai kesempatan yang sama untuk dipilih menjadi sampel penelitian. Adapun jumlah sampel yang diambil adalah 92 orang.

Instrumen penelitian ini menggunakan Kuesioner/angket yang berkaitan dengan keterlibatan dan motivasi belajar siswa. Dalam penelitian ini, penulis menggunakan angket tertutup yang disajikan dengan serangkaian alternatif dan responden cukup memilih jawaban yang telah disediakan. Penyebaran kuesioner dalam bentuk google form dibantu oleh guru PJOK melalui grup Whatsapp kelas. 
Penelitian ini dilaksanakan dalam dua tahap yaitu pada tanggal 22 juni-24 Juni 2021 yang digunakan untuk uji coba instrumen dan pada tanggal 09 Agustus-14 Agustus 2021 pelaksanaan penelitiannya.

\section{HASIL DAN PEMBAHASAN}

\section{Hasil Penelitian}

Data dalam penelitian ini bersumber dari Siswa SMPN 1 Arjawinangun dengan berjumlah 92 Siswa. Diperoleh data sebagai berikut :

Tabel 1. Deskripsi Motivasi Belajar Dan Keterlibatan Siswa SMP N 1 Arjawinangun

\begin{tabular}{ccccccc}
\hline Variabel & N & Maksimum & Minimum & Mean & $\begin{array}{c}\text { Std. } \\
\text { Deviasi }\end{array}$ & Varians \\
\hline $\begin{array}{c}\text { Motivasi } \\
\text { Belajar Siswa }\end{array}$ & 92 & 114 & 72 & 94,43 & 10,0311 & 100,622 \\
$\begin{array}{c}\text { Keterlibatan } \\
\text { Siswa }\end{array}$ & 92 & 74 & 44 & 59,97 & 6,1794 & 38,1857 \\
\hline
\end{tabular}

Dari deskripsi hasil penelitian tentang motivasi belajar siswa dalam pembelajaran daring pendidikan jasmani, dengan rata-rata dari 92 responden sebesar 94,43 (78,70\%). Motivasi belajar siswa dalam pembelajaran daring pendidikan jasmani yang berkategori sebagai berikut: Sangat tinggi berjumlah 31 siswa (34\%), kategori tinggi berjumlah 60 siswa (65\%), kategori rendah 1 siswa (1\%) dan pada kategori sangat rendah berjumlah 0 siswa $(0 \%)$.

Adapun keterlibatan siswa dalam pembelajaran daring pendidikan jasmani, dengan rata-rata dari 92 responden sebesar 59,97 atau 74,96\%. Keterlibatan siswa dalam pembelajaran daring pendidikan jasmani yang berkategori sebagai berikut: Sangat tinggi berjumlah 15 siswa (16\%), kategori tinggi berjumlah 75 siswa (82\%), kategori rendah 2 siswa (2\%) dan pada kategori sangat rendah berjumlah 0 siswa (0\%).

\section{Pembahasan}

Berdasarkan hasil penelitian yang menunjukkan bahwa motivasi siswa berkategori tinggi. Ada beberapa faktor yang mempengaruhi motivasi belajar siswa tinggi yaitu, faktor internal : siswa sudah bisa beradaptasi dengan pembelajaran daring, bisa mengakses 


\section{Journal Respecs}

layanan daring termasuk memanfaatkan bantuan kuota internet dari Kemendikbud. Faktor internal yaitu, guru sudah bisa menciptakan lingkungan belajar yang kondusif. Dengan sajian media pembelajaran yang variatif, pemberian tugas yang terjadwal, serta peran dan dukungan orang tua. Khusus untuk peran orang tua yang tercermin selama masa pandemi Covid-19: adalah pendampingan anak dalam mengerjakan tugas sekolah. Dan pengawasan kegiatan bersama selama di rumah. Serta menciptakan lingkungan yang nyaman untuk anak (Waldiah, 2021).

Berdasarkan hasil penelitian yang menunjukkan bahwa keterlibatan siswa berkategori tinggi. Pencapaian hasil keterlibatan siswa yang tinggi tidak terlepas dari banyaknya aspek yang mendukung pembelajaran daring. Diantaranya peran Motivasi belajar siswa. Keterlibatan siswa adalah perwujudan dari motivasi yang dilihat melalui tindakan, kognitif, dan emosi yang ditampilkan oleh siswa, mengacu pada tindakan berenergi, terarah, dan tetap bertahan ketika mendapatkan kesulitan atau kualitas siswa dalam interaksinya dengan tugas akademik. (Ariani, 2019)

Pelaksanaan penelitian ini dilakukan semaksimal mungkin sesuai dengan tujuan penelitian. Namun masih terdapat keterbatasan dan kelemahan, yaitu. Proses pengamatan penelitian hanya dilakukan peneliti. Para peneliti tidak dapat mengontrol seberapa serius setiap responden ketika mengisi kuesioner. Antara lain, kejujuran responden.

\section{KESIMPULAN}

Tingkat motivasi belajar dan keterlibatan siswa SMPN 1 Arjawinangun pada pembelajaran daring pendidikan termasuk kategori Tinggi. Yang berarti pembelajaran daring masih memberikan kontribusi dalam memotivasi dan mengajak siswa dalam proses pembelajaran pendidikan jasmani. Terlepas dari itu pembelajaran daring masih memiliki banyak kekurangan terutama dalam penyediaan peralatan pembelajaran daring, metode dan media pembelajarannya, sehingga diperlukan penelitian lanjutan.

\section{DAFTAR PUSTAKA}

Ariani, L. 2019. Keterlibatan Siswa (Student Engagement) Di Sekolah Sebagai Salah Satu Upaya Peningkatan Keberhasilan Siswa Di Sekolah. Journal UMBJM.

Badriah, Dewi, L. 2012. Metodologi Penelitian Ilmu-Ilmu Kesehatan. Bandung: Multazam Bandung.

Cahyani, A., Listiana, I. D., \& Larasati, S. P. D. 2020. Motivasi Belajar Siswa SMA pada Pembelajaran Daring di Masa Pandemi Covid-19. IQ (Ilmu Al-qur'an): Jurnal Pendidikan Islam, 3(01), 123-140.

Emda, A. 2018. Kedudukan Motivasi Belajar Siswa Dalam Pembelajaran. Lantanida Journal, 5(2), $172-182$. 
Hudah, Maftukin dkk. 2020. Analisis Pembelajaran Pendidikan Jasmani Pada Masa Pandemik Covid-19 Ditinjau Dari Penggunaan Media Aplikasi Pembelajaran dan Usia Guru. Journal Pendidikan Jasmani Kesehatan dan Rekreasi (PORKES) Vol.3, No.2, Desember 2020, Hal. 93-102.

Komarudin dan Prabowo, Mardianto. 2020. Persepsi Siswa Terhadap Pembelajaran Daring Mata Pelajaran Pendidikan Jasmani Olahraga Dan Kesehatan Pada Masa Pandemi Covid-19. Majalah Ilmiah Olahraga (MAJORA) vol 26 (2) 2020, 56-66

Nurdyansyah dan Eni Fariyatul F. 2017. Inovasi Model Pembelajaran Sesuai Kurikulum 2013. Sidoarjo: Nizamia Learning Center

Purbawati, C., Rahmawati, L. E., Hidayah, L. N., \& Wardani, L. S. P. 2020. Tingkat Partisipasi Siswa Sekolah Menengah Pertama Dalam Pembelajaran Daring Di Masa Pandemi Covid-19. Refleksi Edukatika: Jurnal Ilmiah Kependidikan, 11(1), 102-108.

Siyoto, Sandu dan Sodik, M Ali. 2015. Dasar Metodologi Penelitian. Yogyakarta: Literasi Media Publishing.

Waldiah, S. 2021. Peran Orang Tua dalam Pembelajaran di Masa Pandemi. Radar Semarang Jawa Pos. 